Hope College

Hope College Digital Commons

Faculty Publications

Winter 2011

\title{
C. S. Lewis and René Girard on Desire, Conversion, and Myth: The Case of Till We Have Faces
}

Curtis A. Gruenler

Hope College, gruenler@hope.edu

Follow this and additional works at: https://digitalcommons.hope.edu/faculty_publications

Part of the English Language and Literature Commons

\section{Recommended Citation}

Gruenler, Curtis. "C. S. Lewis and Rene Girard on Desire, Conversation, and Myth: The Case of Till We Have Faces" Christianity and Literature Winter 2011 (60.2): 247-265.

This Article is brought to you for free and open access by Hope College Digital Commons. It has been accepted for inclusion in Faculty Publications by an authorized administrator of Hope College Digital Commons. For more information, please contact digitalcommons@hope.edu. 


\title{
C. S. Lewis and René Girard on Desire, Conversion, and Myth: The Case of Till We Have Faces
}

\author{
Curtis Gruenler
}

[Published in Christianity and Literature 60.2 (Winter 2011): 247-265.]

Author's Note: Earlier versions were presented at the meeting of the Colloquium on Religion and Violence in Riverside, CA, in June 2008 and at the meeting of the C. S. Lewis and Inklings Society in Grand Rapids, MI, in March 2009. I would also like to thank my colleagues Charles Huttar, Martin Kevorkian, and Peter Schakel and my student Peter Kleczynski for their comments.

In 1961, René Girard published a landmark work of literary criticism, translated four years later as Deceit, Desire, and the Novel, which began one of the great intellectual projects of the second half of the twentieth century: a theory of culture that offers new ways of understanding desire, myth, the historical importance of the biblical revelation, and much else. While working on this book, Girard had experienced a conversion to Christianity and joined the Roman Catholic Church, in which he remains a regular participant (Girard, "Epilogue" 283-6). C. S. Lewis was perhaps the most famous Christian intellectual in the English-speaking world at this time, and the careers and work of the two men show striking parallels. Both were trained as medievalists. Lewis too converted to Christianity at the beginning of his academic career, during the work that 
went into his own first, landmark book, The Allegory of Love (1936). Like Deceit, Desire, and the Novel, it centers on literary representations of love and desire, but treats the Middle Ages up through Spenser, stopping just short of Cervantes, with whom Girard begins. Of course Lewis, unlike Girard, went on to write fiction as well. In 1956, he published Till We Have Faces, his last novel and perhaps his most penetrating exploration of themes that had occupied his career as both scholar and novelist, and which would later occupy Girard: love and desire, myth, and Christianity.

Yet despite the parallels between the careers and interests of these two men, who are arguably among the most important literary critics of the twentieth century and certainly among the most important of those who are openly Christian, they seem an odd combination, opposite in style and in views on some of the things that most interested them. One is thoroughly English, the other typically French (though Girard has spent his academic career in the U.S.). Lewis wrote before the proliferation of literary theory (though with more methodological reflection than most critics of his generation), while Girard was a participant in bringing French theory to America (though he has also been one of its strongest critics). ${ }^{1}$ Above all, they seem to take opposite views of myth, which in turn lend differing shades to their views of everything else. For Lewis, many of the greatest myths anticipate and are fulfilled by Christianity, and he commonly uses the term to refer to a kind of story that he greatly valued for its power to communicate truth. ${ }^{2}$ For

\footnotetext{
${ }^{1}$ For an overview and assessment of Lewis as critic and theorist, see Calin 85-100. Girard helped organize the epochal 1966 conference at Johns Hopkins entitled "The Languages of Criticism and the Sciences of Man" at which Jacques Derrida turned the rising tide of structuralism into the tsunami of poststructuralism with his paper "Structure, Sign, and Play in the Discourse of the Human Sciences" (included in the proceedings published as The Structuralist Controversy, ed. Richard Macksey and Eugenio Donato). For a later critique of "theory," see Girard's "Theory and Its Terrors."

2 Though the similarity of Christianity to many myths was part of what turned him away from Christianity in his youth (Surprised by Joy 62-3), when he returned to it as an adult, he explained himself in a letter to his friend Arthur Greeves by saying that "the story of Christ is simply a true myth" (977).
} 
Girard, however, myth is a distortion, a lie that functions precisely to conceal the allimportant truth about scapegoating violence that is revealed in the Bible. Lewis's emphasis on continuity between myth and gospel leads him to a Christianity of vivid mysteries, an even mystical sense of the world penetrated by symbols of transcendent divinity. Girard's contrast between myth and gospel, on the other hand, follows from what he calls an anthropological reading of the Bible, that is, the gospel as the key to the truth about humanity that has been obscured by stories of gods. This truth has much to do with Girard's view of desire, which also would seem to differ greatly from Lewis's. Girard is known for his theory of mimetic desire as the driving force of human violence. Lewis, however, is more known for a view of desire continuous with love and capable, like myth, of leading to the divine and being taken up within it.

A strict opposition between their views of desire, however, quickly breaks down. Girard sees a positive side of mimetic desire as making humans capable of freedom, both in a general sense and in the specifically Christian sense of imitating Christ. Lewis, for his part, is certainly alert to the perversions of love and to desire's capacity to obscure the work of grace. Till We Have Faces in particular manifests a complex understanding of both desire and myth, one that Girard's cultural theory can clarify. For Girard, literature at its best is theory in the sense that it offers supreme understanding of humanity, including the function of literature itself and even how to read a given work. ${ }^{3}$ Lewis's novel belongs in that Girardian canon; it embodies insights that anticipate key aspects of Girard's thought, but uses a special sort of narrative, rather than theoretical discourse, in order to interpret itself and its representation of the human condition. Till We Have Faces stages the shadowy work of myth to conceal violence and block self-knowledge, but also

\footnotetext{
${ }^{3}$ See Doran xiv.
} 
the potential of something very like it to provoke enlightenment and conversion. Here, then, at a sort of mid-century hinge between the construction of mythopoeic visions by Lewis (and his Oxford Inklings friends such as J. R. R. Tolkien) and the subsequent deconstruction of mythology by Girard (even as much else was being deconstructed around him by others), Lewis's novel can be seen to encompass both dark and light for a full-orbed representation of the sacred as both lie and truth.

Certain myths had never ceased to fascinate and move Lewis, and he came to see them as essential means by which truths of the gospel that surpass rational understanding had been made persuasive to him. In his late work Experiment in Criticism (1961), he defines myth according to its effects on its audience rather than its content. It is a kind of story that becomes "a permanent object of contemplation" apart from the qualities of how it is told in any given instance; reading it "may be sad or joyful but it is always grave" and "awe-inspiring" (43-4). ${ }^{4}$ For him these stories seem to be mostly old, like those of Orpheus and Balder, but could be recent, like Dr. Jekyll and Mr. Hyde or Kafka's The Castle. In Till We Have Faces, Lewis refashions one of the ancient stories that had long intrigued him, the tale of Cupid and Psyche as told within the second-century Metamorphoses or Golden Ass of Apuleius. ${ }^{5}$ Among the many changes by which Lewis makes a novel out of the ancient tale, commonly interpreted as a Platonic allegory of the

\footnotetext{
${ }^{4}$ Lewis here lists six characteristics of myth in all. For comments on them with respect to Till We Have Faces, see Myers 183-7.

${ }^{5}$ Here is a brief summary of the story in Apuleius (Lewis gives a fuller summary in a long note appended to Till We Have Faces, 311-13): Psyche, youngest of a king's three daughters, is so beautiful that Venus is jealous of her and Cupid, sent to afflict her, falls in love with her instead. When she goes willingly to be sacrificed on a mountain, he takes her away to a palace where he enjoys her love but forbids her to see his face. She asks that her sisters be allowed to visit, and they become jealous of the palace and convince her to violate the prohibition. Cupid leaves her, but they are eventually restored to each other after Psyche performs, with mysterious help, four impossible tasks set by Venus.
} 
journey of the soul (psyche in Greek), ${ }^{6}$ a signal one is to the character of Psyche. The innocence that in the tale seems naively trusting and rather passive becomes, in Lewis's richer characterization, wiser and full of the kind of salvific desire that he found to be central to his own response to his favorite myths. Indeed, the title of his autobiography, Surprised by Joy, published the year before Till We Have Faces, refers to the importance of such desire in his conversion. In the novel, it first appears in Psyche's longing for the Grey Mountain where she will later encounter the god (the unnamed figure who takes the place of Apuleius's Cupid but here comes to signify Christ). In the autobiography, Lewis recalls a longing for the mountains as one of his first "aesthetic experiences" (7; he defines what he means by Joy at 17-18, and how he began to associate it with myths at 72-3). A related change from Apuleius makes the persecution of Psyche not a plot of the gods but a human sacrifice driven by an apparently opposite, consuming sort of desirethe kind that Girard associates with myth and which his theory can help illuminate. Thus while Psyche as well the god are in Lewis's story mythopoeic reflections of true divinity, she is also the victim of the kind of violence that, in Girard's view, produces the false gods of mythology.

An overview of Girard's theory will help at this point, though he develops from it a much more complex analysis of culture, especially the development of Western culture, than this brief summary will suggest. The kind of myth behind which Girard finds violence is what Lewis specifies in Experiment in Criticism that he is not talking about, the kind of stories anthropologists collect and call myths (42; most of such stories, says Lewis, "are to us meaningless and shocking"). The traditional, foundational myths of all cultures, according to Girard, share features that derive from acts of real violence, which

\footnotetext{
${ }^{6}$ For a recent view of the tale as Platonic and citations of others, see Panayotakis, "Vision and Light."
} 
the myths in turn conceal behind the veil of what Girard calls "the sacred" in a sense that opposes it to the Christian gospel. ${ }^{7}$ The production of the sacred through scapegoating violence is the second of the two core ideas of his theory of culture, and it follows from the first: mimetic or triangular desire. Human desire, beyond basic appetites for bodily needs, is imitative. We want what we see, or imagine, other people wanting. Even the way we go about satisfying basic needs, such as for food and clothing, are imitative (as advertisers well know). Further, the models of our desires for objects tend to become rivals for those objects, and the rivalries can become so intense as to displace the initial object from attention altogether. Such escalation from acquisitive desire to conflict is obvious, for example, in children fighting over toys and in love triangles, yet we have such a strong investment in the individuality, authenticity, and rationality of our desires that their imitative origins remain hidden. ${ }^{8}$ Girard argues in Deceit, Desire, and the Novel that the great novels of Cervantes, Stendhal, Flaubert, Proust, and above all Dostoevsky distinctively expose the mimetic nature of desire. Indeed, they are stories of conversion that climax in their protagonists' discovery of the imitative nature of their own desiresthink of Quixote recognizing and finally repudiating his imitation of the fictional knight, Amadis of Gaul. And Girard suggests further that the conversions of the protagonists follow from conversions in the lives of the authors themselves-conversion, that is, in the sense of recognizing the falsity of the desires they had taken to be essential to their true

\footnotetext{
${ }^{7}$ See, among others, The Scapegoat 24-44 and I See Satan 62-66.

${ }^{8}$ Love triangles are a common feature of the tradition of courtly love treated by Lewis in The Allegory of Love. William Calin suggests that his controversial identification of adultery as one of the essential traits of courtly love would be better replaced by a more general notion of obstacle (96). This more Girardian explanation shows Lewis's early interest in the dynamics of desire that play out in the much different setting of Till We Have Faces. Girard notes Denis de Rougemont's later insight into the importance of obstacles for courtly (or romantic) love (Deceit, 165).
} 
selfhood and being delivered through this knowledge from possession by them (Deceit 290-314).

Girard's second main idea also involves conversion, in this case the cultural conversion caused by the Judeo-Christian demystification of mythology. The violence Girard finds concealed behind the myths and rituals of archaic religion is the basic mechanism that allows communities to maintain order in the face of escalating mimetic rivalry. He imagines a heuristic primordial scene in which a tribe's mimetic desire for the same object leads to a conflict of all against all, which is resolved when all the violence is directed, mimetically, against one victim, who is collectively murdered. The peace that results seems like a miraculous deliverance and is attributed to the victim, who is now deified and made the protagonist of a story that gets passed down as a myth. Sacrificial rituals repeat the same mechanism in more controlled fashion. ${ }^{9}$ Myths not only conceal the original act of violence but also perpetuate more violence, ritual and otherwise, by establishing the sacredness of power and the guilt of victims. The biblical tradition, on the other hand, tells the same stories of the persecution of victims but from a perspective that sees the victims as innocent and reveals what Girard (using the indispensable term coined by Tyndale in translating Leviticus 16) calls the scapegoat mechanism. For Girard, the God of the Bible gradually emerges from behind projections of human violence. In Jesus, God becomes the supremely innocent victim of the scapegoat mechanism in order to reveal it fully. Thus conversion, for a culture as a whole as well as for individuals, involves turning from the lies of myth to the truth of the gospel. Desire

\footnotetext{
${ }^{9}$ Other, later institutions of culture are more complex ways of restraining the contagion of mimetic desire and purging it through the designation of victims. Girard's fullest account of archaic culture is Violence and the Sacred and his best account of the Judeo-Christian demystification is I See Satan Fall Like Lightning.
} 
remains mimetic, but the model chosen is the loving and patient one of Christ rather than the acquisitive and conflictual ones of mimetic rivals.

Lewis makes Till We Have Faces a conversion story by centering it not on Psyche but on Orual, her oldest sister and the story's narrator. The novel ends with Orual being set free to imitate her sister's devotion to the god. Orual's conversion pivots, as Girard implies it does with real authors of conversion novels, on the writing of her story. This act of writing begins as self-defense, provoked by hearing a priest's version of Psyche's story, and divides the novel into its two parts. Thus part 1, which tells most of Orual's life, represents it through a complex mixture of acquired objectivity, growing understanding, and continued, resentful self-deception. The much shorter part 2 tells, with converted lucidity, of her further conversion through the encounters and visions that writing part 1 had opened her to. Some things, however, Orual seems to see clearly from the start, and these eventually guide her to further revelations.

Orual's education, with which the book begins, enables her to see the actions of those around her, in a small kingdom somewhere in the far hinterlands of the Eastern Mediterranean during the Hellenistic period, in a way not completely dominated by the cult of the local goddess, Ungit. Orual is schooled in skeptical, Stoic rationalism by a Greek slave they call the Fox, and both of them become devoted to Psyche from the moment she arrives. When Psyche's extraordinary beauty eventually leads her to be offered on the mountain as a sacrifice to deliver the kingdom from a plague, Orual's Greek objectivity together with her love for Psyche enable her to see that Psyche is an innocent victim of the scapegoat mechanism. Of course this is not spelled out in so many words, but Orual's narration includes sufficient hints of a Girardian analysis of sacrificial 
ritual. Rather than seeing Psyche as the necessary victim because of her guilt (the common people's view) or her perfection (the king's view), Orual, like Girard, sees the choice of victim as essentially random. Orual follows her father, the king, in affirming the logic that one should die for many, but then suggests that any victim will do by offering herself as a substitute for Psyche. ${ }^{10}$ Similarly, Orual's narration shows the sacrifice coming about as a result of the two conditions that Girard sees commonly at work in scapegoating: conflict arising from mimetic desire and a crisis like a plague or famine that pushes the conflict over the brink. Both famine and plague are happening in Lewis's story, and the mimetic behavior of the crowd appears first when they imitate each other in desiring Psyche's supposedly healing touch and again more obviously when they suddenly turn and accuse her of bringing the plague. Orual hints at the mimetic tendencies of what she calls the "mob" when, just before she receives the news from her nurse Batta that the crowd has turned on Psyche, she notes what a mimic Batta always was $(35,37)$. After Psyche has been offered on the mountain, the crowd imitate each other again in calling her the Blessed. Of course Orual does not join in this. Psyche remains for her a human victim rather than some kind of deity. To Orual, what sets Psyche apart is not being sacrificed but rather how she responds to it: her mysterious desire for the god of the Mountain and her capacity to pity her persecutors, to accept being offered as a ransom, and to suffer patiently. Psyche's response to her persecution

\footnotetext{
${ }^{10}$ As Charles Huttar points out in a forthcoming article, Orual's insight echoes the words of Caiaphas in John 18:14. Girard finds in this verse an acknowledgement of gospel truth from the mouth of one of its enemies. For Girard, the choice of victim is essentially random in the sense that it is determined by a mimetic contagion that can fix on a member of the group set apart by the slightest difference. Orual mentions earlier that her Greek tutor, the Fox, had taught her to see the priest of Ungit as a schemer, but the priest's own air of assurance persuades her otherwise. The scene is a good illustration of Girard's principle that the single-victim mechanism can tolerate no doubt about its righteousness and inevitability if it is to work.
} 
reinforces Orual's conviction of Psyche's innocence and her persecutors' guilt, an effect much like Girard sees Christ's Passion having on his disciples.

Whereas Orual's certainty that Psyche is innocent allows her to see through the cult of Ungit, her insistence on her own innocence blinds her to her own involvement in mimetic rivalry. At the end of part one, after Orual tells of her two journeys to see Psyche on the mountain and her subsequent career as queen, she concludes with the event that has provoked her to write her story: coming across a shrine dedicated to Psyche as a new goddess. The temple priest, unaware of the real story and who Orual is, explains how this new goddess has become the focus of an annual cycle of ritual. When the priest begins to describe the ritual, Orual interrupts him after the word "offer" (246), and as Peter Schakel points out, the next word would no doubt be "sacrifices" (Reason and Imagination 63). Lewis's novel thus imagines how ancient myth and ritual develop from, and rewrite, real acts of sacred violence, just as Girard suggests. The priest's rendition of Psyche's story resembles that of Apuleius, Lewis's source, including some details that especially provoke Orual to tell her own, corrective version. Rather than attributing the sacrifice of Psyche to human violence, the priest blames it on Ungit's envy of her beauty, just like Apuleius blames Venus's envy. Orual revealingly judges such envy to be childish, but what she most objects to is that the older sisters are said by the priest (as by Apuleius) to have seen the palace that Psyche shared with the god on the mountain until, out of jealousy, they convinced her to violate his prohibition against looking at him. Lewis's careful handling of the question of whether the palace is real, or rather in what sense it is real, and whether Orual sees it, is part of what makes the story mythopoeic in a positive sense, and an issue to which we will return. Though Orual's narration includes a brief 
vision of it, it is not visible to her normal senses, and in the story she decides she did not see it, it cannot be real, and she must save Psyche from delusion by bringing her a lantern to expose whatever it is that comes to her by night. When Orual hears the priest's story, she rejects the idea that she is jealous of Psyche and maintains that she is an innocent victim of invisible gods. She tells the priest, "I think the Sister-or the Sisters—might have more to say for themselves than you know," and his reply points to what Orual is as yet unable to see about herself: "You may be sure that they would have plenty to say for themselves.... The jealous always have" (246-7). Orual's preoccupation with the conflict between the religion of Ungit and Greek skepticism, as well as with her own struggles, have kept her from recognizing her own envy. From a Girardian perspective, Orual typifies how we all conceal our own mimetic rivalry and consequent envy from ourselves, even as we can recognize it in others. ${ }^{11}$

Orual begins to see herself more clearly in part 2 through two encounters with people who had been involved in situations of triangular desire with her. The first is Tarin, formerly one of her middle sister Redival's lovers but now a eunuch employed by a distant emperor and thus able to see the past more dispassionately. He points out to her how lonely and pitiable Redival had been after Psyche arrived. Psyche herself had been able to see this, but Orual could not because she saw herself as the pitiable one. Now Orual begins to realize that she was unable to pity Redival because she was jealous of her blond curls, that is, of the attention Redival got from suitors like Tarin, that Orual herself

\footnotetext{
${ }^{11}$ Lewis's earliest attempts at rewriting the story before his conversion to Christianity started with changing the story from Apuleius so that the older sisters do not see the palace (Hooper 246), and might have produced something like part 1 of the book, in which Orual is still justifying herself. They would then have been the kind of self-justification that Girard sees in failed novels ("Epilogue" 284), whereas the finished novel, in showing the influence of Lewis's conversion as he had recently retold it in Surprised by Joy, perhaps suggests also the effect that writing the aborted versions of Psyche's story had had on him decades earlier.
} 
wanted, and that Redival was her rival and obstacle for. It is perhaps worth noting how close the name Redival is to the word rival, and indeed Orual's recollections in part 1 had begun with their rivalry when the two sisters had their hair cut and Orual noticed how the slaves admired Redival's hair but not her own (5).

Next, in part 2, Orual comes to understand the mimetic rivalry involved in her unrequited love for the captain of her guard, Bardia. After Bardia's death, when she goes to see his widow Ansit, Orual realizes that, in the competition for his love they had each imagined, each had thought the other was winning. Whatever the relative nature and extent of each woman's relationship with Bardia, the rivalry between them, though they barely knew each other, had made them such mutual obstacles as to prevent either one from fully enjoying what she had. Orual had even considered in part 1 the possibility that Ansit might be jealous of her, but had been unable to acknowledge her own jealousy, so that the thought only further inflamed her desire for him, her sense of herself as victim, and her compensatory styling of herself as manly (233). ${ }^{12}$ The mimetic nature of Orual's desire is further implied by the fact that after she discovers her jealousy, her craving for Bardia ends. The desire that could persist in the absence of its object cannot endure the end of the rivalry. Moreover, she writes, “... when the craving went, nearly all that I called myself went with it. It was as if my whole soul had been one tooth and now that

\footnotetext{
${ }^{12}$ Much earlier (146), there is a hint that Orual's rivalry with Ansit is caught mimetically from the Fox, who refers disparagingly to the hold Bardia's wife has over him and compares him to Alcibiades, the famous case of failed ascent to higher forms of love from Plato's Symposium. Even earlier, the narrative also hints that the Fox is the model for Psyche's more transcendent longing for the Mountain, first mentioned in connection with his taking her to a place from which to view it (23). The Fox is typical of one whose commitment to enlightenment leaves him unenlightened about his own mimetic desire, though the episode about Alcibiades in part 3 of the Symposium might be read as Plato's attempt to confront the persistently imitative nature of eros. This is also perhaps the place to mention that Lewis, on at least one occasion, questioned whether the particular kind of longing he called Joy is really so distinct from other kinds of desire or rather "part of the Old Man and must be crucified before the end" (The Problem of Pain 137; discussed by Farrer, 40).
} 
tooth was withdrawn. I was a gap" (267). The infected tooth, we might say, was the mimetic rivalry that, while it was unrecognized, had become the center of Orual's sense of herself as queen with Bardia as her captain. Longing for him, kept alive in a sort of friendship twisted by unacknowledged envy of the marital love denied her, had kept her from facing her own emptiness. ${ }^{13}$ With the void in her being exposed, Orual can receive anew, in the book's final visions, what has really been the center of her identity, her relationship with Psyche and, through her, with the god.

Orual's relationship with Psyche involves a more complex rivalry, and her conversion happens not so much through understanding clearly the mimetic dynamics she has been blind to as it does through seeing and accepting a new kind of relationship. Yet there is, in Orual's insight, during the second of the four visions that conclude the book, that she herself is Ungit, "gorged with men's stolen lives," a certain recognition that her love for others, perhaps including Psyche, was not innocent (276). ${ }^{14}$ Orual's relationship with Psyche is a triangular one that also includes as its third member the god who has in truth rescued Psyche. For Orual, each of the others, Psyche and the god, are both object of desire and rival. Desire for the love of Psyche puts Orual in rivalry with the god who has chosen Psyche as his bride, while less consciously Orual also imitates Psyche's desire for the god and thus enters into rivalry with her. Because Psyche is closer to Orual in status and the god is on another level of being, however, the frustrations of mimetic desire develop quite differently in each case, that is, in her relationships to Psyche and to

\footnotetext{
${ }^{13}$ See Girard, A Theater of Envy, 4 (emphasis original): "Like mimetic desire, envy subordinates a desired something to the someone who enjoys a privileged relationship with it. Envy covets the superior being that neither the someone nor the something alone, but the conjunction of the two, seems to possess. Envy involuntarily testifies to a lack of being that puts the envious to shame.... That is why envy is the hardest sin to acknowledge."

${ }^{14}$ Lewis describes Orual in a letter as "an instance, a 'case', of human affection in its natural condition: true, tender, suffering, but in the long run, tyrannically possessive and ready to turn to hatred when the beloved ceases to be its possession" ("To Clyde Kilby," 831).
} 
the god as model/obstacle. ${ }^{15}$ Orual cannot successfully compete with the god for Psyche, so her desire is simply thwarted and can then be romanticized as pure and ennoblingjust as the fictional Amadis of Gaul cannot be a real rival for Quixote, who can then idealize imitating him. Thus Orual, whether or not she believes in Psyche's god, can retain a view of herself as the one who truly and innocently loves Psyche. In rivalry with Psyche for the favor of the god, on the other hand, Orual is an equal and thus compelled to continue competing. When Psyche appears peaceful and strong, blessed by her devotion to the god, Orual is jealous. Then she is Ungit as the goddess to whose envy the sacrifice of Psyche is attributed both by the priest of the new goddess and by Apuleius. When Psyche is vulnerable, on the other hand, Orual fantasizes about having in herself a fullness of being that enables her to offer comfort.

In her career as queen, Orual pursues and even to a degree achieves her own sort of divinity by making herself impervious to harm and an object of awe to her subjects. ${ }^{16}$ On the surface of her narration in part 1 is a Greek, rationalist attempt at self-mastery, which cannot acknowledge the mimetic influence of others. But underneath, her unrecognized rivalries with both Psyche and the god make her at once doubt the existence of the true god and aspire to be a sort of god in competition with others for the lives of her subjects, particularly those closest to her such as Bardia. By veiling herself, removing herself from her people, Orual summons their mimetic desire through what Girard sees as a deviation of the true asceticism of a mystic seeking God (Deceit 155-6). Orual's general

\footnotetext{
${ }^{15}$ It might help to think of an isosceles triangle with a short base and two long sides, Orual and Psyche at the lower corners joined by the short side, and the god at the top vertex that joins the long sides. On the two kinds of frustration that mimetic rivalry leads to, see Girard's "Conversion in Literature and Christianity," 264. In Deceit, Desire, and the Novel, p. 9, Girard calls these external mediation (Orual's rivalry with the god) and internal mediation (her rivalry with Psyche).

${ }^{16}$ Chad Schrock explores the complexities of Orual's mimetic rivalry with the gods, though without reference to Girard's theory, in "A Myth of Hubris."
} 
asceticism as queen, pursuing neither sexual pleasure as a woman nor the pleasures of men that her role as sexless queen opens to her, fits a typical reaction Girard finds in those caught in mimetic desire. Because a display of desire only inflames rivalry, apparent indifference becomes a further strategy of winning the object. Further along the same road is masochism, the result of despair, which is at work when Orual is willing to drive a dagger into her own arm in order to force Psyche to violate the god's prohibition. Both aspects of the triangle collapse on Orual at this point: she remains in rivalry with Psyche for the love of the god that she has momentarily convinced herself does not exist, yet her conscious desire has come to focus entirely on Psyche, rivalry for whom pits her against this god. She becomes the one who, in thinking to sacrifice herself, in fact sacrifices Psyche by causing her to lose the god's presence.

Whereas most novels keep mimetic rivalry on the level of human models and obstacles, Lewis's novel, with its active divinity, in this respect more closely parallels the Bible itself. Perhaps the most important instance in which Girard has addressed the divine as potential rival is the case of Jesus rebuking Peter, calling him Satan and a scandal, which he sees as Christ's refusal to take Peter as a model of desire and enter into rivalry with him (I See Satan 33). Orual, in tempting Psyche to disobey the god, scandalizes her by insisting that she imitate Orual's own desire, which is essentially a narcissistic selflove (though warped by rivalry into what looks more like self-hatred). That the temptation succeeds might be seen as indicating Psyche's weakness, but her choice is in the end a generous, sacrificial one that will eventually turn rivalry with Orual into a better sort of imitation. For Girard, Jesus himself is only ever a model of good, non-possessive and non-rivalrous, sacrificial desire. Likewise, the Christian God as an object of love is 
not subject to scarcity and thus to rivalry. ${ }^{17}$ The idea of God (misunderstood) as a rival is, however, central to Lewis's novel and makes it a powerful extension of the mimetic theory. He wrote to a friend, “As you see, tho' I didn't start from that, it is the story of every nice, affectionate agnostic whose dearest one suddenly 'gets religion,' or even every luke warm Christian whose dearest gets a Vocation. Never, I think, treated sympathetically by a Christian writer before” (“To Katharine Farrer” 590). Even more pointedly, he wrote to another friend: "The main themes are 1. Natural affection, if left to mere nature, easily becomes a special kind of hatred. 2. God is, to our natural affections, the ultimate object of jealousy" ("To Father Peter Milward SJ" 1090). ${ }^{18}$ What Lewis means by natural affections may not be exhausted by mimetic desire, but the narrative itself suggests a strong applicability of Girard's theory. Mimetic rivalry makes Orual unable to see the beauty of the god, or able to see it only as terrifying, while it keeps her from seeing that Psyche could love Orual all the more now that she loves the god first, or that the god could love them both. Like Peter and Paul, or like the older brother in the parable of the Prodigal Son, Orual misunderstands divine favor as exclusive, and like the two saints she receives visions that enable her conversion toward a truly divine model of desire. $^{19}$

The visions that complete Orual's conversion rework the impossible tasks in Apuleius by which, with supernatural aid, Psyche wins back the love of Cupid. The last and longest vision begins with Orual seeing herself as the one assigned to fill a bowl with

\footnotetext{
${ }^{17}$ Dante expresses this well at Purgatorio 15.49-78.

${ }^{18}$ In his later essay The Four Loves (1960), Lewis develops, in the various kinds of love, the contrast between their merely natural state and their elevation by a higher, divine love; on Till We Have Faces as an embodiment of this thinking, see Peter Schakel's chapter in the forthcoming Cambridge Companion to C. S. Lewis.

${ }^{19}$ Girard discusses the conversions of Peter and Paul in I See Satan (190-1), and I would draw attention also to Peter's vision in Acts 10 .
} 
water from the river of death that runs in the middle of impassible mountains guarded by serpents. As she gives up in despair, she discovers that the bowl is instead a scroll containing her complaint against the gods, and she is taken to the underworld to read it before a gathering of the dead. In making her complaint, she finally recognizes the jealousy that has been at the center of her own soul. Rather than analyzing the mimetic origins of her rivalrous and consuming love, however, she is able to see her view of the gods and her love for Psyche as perverse by contrast to what she has glimpsed in two previous visions. In the first vision too she had seen herself as the one tasked, this time to sort a huge pile of different kinds of seeds. She is supernaturally helped by ants and feels an unusual calm and hope that she associates with Psyche. In the third vision, her task is to gather golden wool from magical but fierce rams; she is crushed when they stampede toward her, but then sees another woman gather wool that was left snagged on thorns. This, of course, is Psyche, as Orual discovers when, in her final vision, she is shown the previous visions again from a third-person perspective as paintings on the walls of a temple. The first and third visions had given her an opportunity to experience an attitude of receiving supernatural goodness as a gift, rather than an object of acquisitive, rivalrous desire. The final vision makes this theme of gift even more explicit when Orual comes to see that, in the first part of it, Psyche had been walking with her, and when she was taken under the mountain to speak her complaint, Psyche's bowl had been filled by a divine eagle. The water of death that fills it could perhaps be taken as the conversion, in the sense of dying to herself, that plays out once Orual passes underground.

The interchanging roles of Orual and Psyche in these visions reveals, beneath Orual's envious rivalry with Psyche for divine favor, a deeper reality of mutual burden- 
bearing in which Orual "bore nearly all the anguish" while Psyche achieved the tasks (300). Earlier, between the second and third visions, when Orual had contemplated throwing herself in the river, she had heard, in a voice that is ambiguously her own, Psyche's, and the god's, "Die before you die. There is no chance after" (279). Girard, following the epigraph to The Brothers Karamazov from the Gospel of John, finds this to be the conclusion of the great novels as well (Deceit 311-12). As the Fox says when he appears in the final vision, Virgil-like, to guide Orual to the Beatrician Psyche, "The Priest knew at least that there must be sacrifices" (295). Dying to oneself and sacrificing oneself for another, however, are not like the sacrifice of a scapegoat. As others have noted, Lewis seems to envision here what Charles Williams called the way of exchange, and I would suggest that this too could be analyzed in mimetic terms. ${ }^{20}$ The burden that one is unable to bear because of being possessed by mimetic rivalry, another who is not so possessed can bear more easily while giving back a model of non-rivalrous, generous desire. Psyche had been a model of such desire all along. ${ }^{21}$ And when Orual finally sees herself in the pool not as Ungit but as a second Psyche, it signifies Orual's inclusion in the love and beauty she had, out of rivalry, believed herself excluded from. Girard points out the common pattern of doubles that results when mimetic rivals become each others' models and their acquisitive desire swallows anything else that would distinguish them

\footnotetext{
${ }^{20}$ See Williams, "The Way of Exchange," as well as his explorations of the related ideas of substitution and co-inherence. Charles Huttar explores the relevance of these ideas in a forthcoming article on Till We Have Faces.

${ }^{21}$ Even before she is taken to the mountain, Psyche can imagine past the projection of human violence onto the gods (71). Love of the god increases Psyche's love for others $(115,158-9)$ and she wants Orual to see the gods too (111). In her parting words to Orual at the end of her first visit, "All will be well" (128), the allusion to the Showings of Julian of Norwich strengthens their assertion of a God beyond scarcity. There are hints in Surprised by Joy that Lewis recognized positive models of desire in his own life, beginning with his older brother in the episode that he recalls as his first experience of joy (7).
} 
(Deceit 101-4). Yet the call to imitate Christ surely also suggests a positive sort of doubling, becoming like Christ in desire, that is figured in Orual's conversion.

These visions use the literary means of fantasy to articulate what might be called a countermyth to the mythology of divine envy and devouring love apparent in the culture that sacrifices Psyche and hidden but equally powerful in the more enlightened, preconversion mind of Orual. Rather than another myth, however, I would call this a fairy tale. Theologian John Milbank proposes a basic distinction between fairy tales, which he identifies as stories focused on surprising gifts, and myths, in which things are "configured as rupture, sacrifice, violence, and fixed contract" ("Fictioning Things" 23). Similarly, Tolkien, in his classic essay "On Fairy-Stories," distinguishes between what he sees as the corrupt uses of fantasy for delusion or domination and its true potential for recovering the givenness of things from possessiveness. This potential finds distinctive expression in what he calls (adding to the defining element of tragedy a Greek prefix for "good") eucatastrophe, the fairy-tale ending that comes as "a sudden and miraculous grace" (153). Till We Have Faces includes, within the frame of a realistic novel, both myth and fairy tale. On one hand, it shows the use of myth to justify sacrificial violence and to nurture lifelong resentment. On the other hand, it escapes from both of these by means of fairy tale. Indeed, within the story, the escape comes not so much by critical exposure of myth as by the provision of a fairy tale alternative. Psyche's tasks give Apuleius's story much of its fairy-tale quality, and Lewis re-imagines them as Orual's 
visions in order to make them serve the grown-up fairy tale, as it were, of her conversion. ${ }^{22}$

In one sense, this distinction of myth and fairy tale takes them to be opposites. Myth lies in order to conceal the truth of human evil. Fairy tale reveals the truth of a good that precedes and outlives human evil. Nevertheless, their common use of the fantastic points to deeper similarities as well. The fantastic is one means by which both myth and fairy tale challenge and solicit interpretation, a poetics of what has been called since the ancient Greeks the enigmatic. ${ }^{23}$ In Till We Have Faces, the first and most challenging element of the fantastic is Psyche's mysterious rescue from death on the mountain to live in a real but, to normal eyes, invisible palace. For Orual this becomes what she calls her riddle: whether the palace is real, and by extension whether its god is real. When she has a brief glimpse of a palace in the mist, she describes it as "labyrinthine," a figure traditionally associated with riddles (132; see Cook 191-6). That the valley Orual sees the rest of the time is a place of great natural beauty suggests that valley and palace might not be completely distinct realities but rather the same thing seen through different eyes. This hint receives confirmation in Orual's final vision, which seems to take place in the palace, now visible to her, but a palace that is joined seamlessly to a natural paradise. Until her final vision, the fact that the gods speak in riddles is part of Orual's complaint. No doubt myth can use the enigmatic to mystify, manipulate, and conceal violence. Early in the novel, the old priest of Ungit asserts, against the Greek demand to

\footnotetext{
${ }^{22}$ Mara E. Donaldson's illuminating study, Holy Places Are Dark Places, takes a similar approach by applying Paul Ricoeur's theory of metaphor in order to interpret Till We Have Faces as what she calls a narrative of transformation.

${ }^{23}$ Cook survey the main terms and images for the enigmatic from the Greeks to the twentieth century in Enigmas and Riddles in Literature, 7-63, and Struck shows "enigma" to be an original and chief Greek term for poetry seen to conceal mysteries in Birth of the Symbol.
} 
see holy things clearly, that the gods "dazzle our eyes and flow in and out of one another like eddies on a river, and nothing that is said clearly can be said truly about them" (50). In so far as mystery marks objects of desire as withheld and thus all the more desirable, it becomes a means of mimetic contagion. In part two, however, Orual recalls this priest's words and transfers them from the context of scapegoating ritual to her visions, which begin to give, not just manipulative dazzle, but some discernable shape to the idea of gods that "flow in and out of us as they flow in and out of each other" (281). Mimetic theory helps resolve this shape further, but Orual's visions hint at the necessarily mysterious truth of desire's converted form. Fairy tale points to what our mimetic tendencies makes it most difficult to see, the gift of love that exceeds our rivalrous desires. Perhaps it can only break through in riddling form, but perhaps this form is also part of how conversion begins. Part of the riddle of joy, of the sweet desire for distant, imagined beauty that loses its savor as soon as it is possessed, is the human reality that mimetic desire grows through models that are also obstacles. Is Lewis's joy, in Girardian terms, a mimetic desire enhanced by the remoteness that blocks it, thus poised on the knife edge between falling into possessive rivalry for what is inferior but more accessible or learning to imitate the Giver of this beauty $?^{24}$ If so, then the enigmatic, the mystery that brings the transcendent near while maintaining its transcendent distance, is among the most providential of obstacles.

Orual comes to acknowledge that the reason the gods don't speak clearly has to do with the veil that has covered her own face from herself and prevented her from seeing. Indeed, as she puts it in the line from which the book's title comes, her deficiency is a more fundamental matter of not being fully formed as a person: "How can [the gods]

\footnotetext{
${ }^{24}$ See Lewis's discussion of psychological vs. spiritual desire in Surprised by Joy, 35-6.
} 
meet us face to face till we have faces?" (294). This line alludes, of course, to 1

Corinthians 13:12, "We see now through a mirror in an enigma, then face to face," and no doubt Lewis had in mind the first part of the verse as well. ${ }^{25}$ The enigmas of fairy tale are one way that the truth of a goodness beyond imagining, of a God beyond violence, breaks in. But at the same time, the deepest and hardest truths about human evil are seen in the mirror of myth once what Girard likes to call the enigma of myth has been resolved in the light of the Gospel. ${ }^{26}$ In both myth and fairy tale, enigmas summon interpretive attention and gather communities of interpretation. The similarities between myth and fairy tale, shared also with more complex forms that refract these stories and invent new fantasies, challenge discernment. Part of Lewis's achievement in Till We Have Faces is to narrate the effects of both myth and fairy tale, as well as the awakening that is part of the conversion from one to the other, in the psychologically rich form of a novel. Its enigmatic ending points to something Girard sees as distinctive about the Gospel narrative: "A Christian conversion is not circular; it never returns to its point of origin. It is open-ended; it is moving toward a totally unpredictable future" ("Conversion in Literature and Christianity" 266).

Hope College

\section{Works Cited}

Calin, William. The Twentieth-Century Humanist Critics: From Spitzer to Frye. Toronto: U of Toronto P, 2007. Print.

\footnotetext{
${ }^{25}$ My translation here renders more directly than does the familiar "through a glass darkly" St. Paul's Greek as well as Jerome's Latin, both of which use the Greek word from which English gets the word enigma, and both of which Lewis likely knew. Enigma was the classical Greek word for riddles that are not mere puzzles but contain mysteries, and it became the common Latin word for riddles of all sorts.

26 "The Enigma of Myth Resolved" is the title of part 2 of I See Satan (47). Despite the sharp contrast he draws between myth and Gospel, Girard also notes that there is "something Christian" in the "false resurrections" of myth (Battling to the End xvi).
} 
Cook, Eleanor. Enigmas and Riddles in Literature. Cambridge: Cambridge UP, 2006. Print.

Donaldson, Mara E. Holy Places Are Dark Places: C. S. Lewis and Paul Ricoeur on Narrative Transformation. Lanham, MD: University Press of America, 1988. Print.

Doran, Robert. "Editor's Introduction: Literature as Theory." Girard, Mimesis and Theory xi-xxvi.

Farrer, Austin. "The Christian Apologist." Jocelyn Gibb, ed. Light on C. S. Lewis. New York: Harcourt, Brace, 1965.

Girard, René. Battling to the End: Conversations with Benoît Chantre. Trans. Mary Baker. East Lansing: Michigan State UP, 2010. Print.

---. "Conversion in Literature and Christianity." Mimesis and Theory 263-73.

---. Deceit, Desire, and the Novel: Self and Other in Literary Structure. Trans. Yvonne Freccero. Baltimore: Johns Hopkins, 1965. Print.

---. "Epilogue: The Anthropology of the Cross: A Conversation with René Girard." The Girard Reader. Ed. James G. Williams. New York: Crossroad, 1996. 262-88. Print.

---. I See Satan Fall Like Lightning. Trans. James G. Williams. New York: Orbis, 2001. Print.

---. Mimesis and Theory: Essays on Literature and Criticism, 1953-2005. Ed. Robert Doran. Stanford: Stanford UP, 2008. Print.

---. The Scapegoat. Trans. Yvonne Freccero. Baltimore: Johns Hopkins UP, 1986. Print.

---. A Theater of Envy: William Shakespeare. New York: Oxford UP, 1991. Print.

---. “Theory and Its Terrors.” Mimesis and Theory 194-213.

---. Violence and the Sacred. Trans. Patrick Gregory. Baltimore: Johns Hopkins UP, 1977. Print.

Hooper, Walter. C. S. Lewis: A Companion and Guide. San Francisco: HarperCollins, 1996. Print.

Lewis, C. S. The Allegory of Love: A Study in Medieval Tradition. London: Oxford UP, 1936. Print.

---. Collected Letters. Ed. Walter Hooper. 3 vols. San Francisco: HarperCollins, 2004-7. Print. 
---. An Experiment in Criticism. Cambridge: Cambridge UP, 1961. Print.

---. The Four Loves. New York: Harcourt, Brace, 1960. Print.

---. The Problem of Pain. 1947. New York: Macmillan, 1973. Print.

---. Surprised by Joy: The Shape of My Early Life. New York: Harcourt, Brace, 1955. Print.

---. Till We Have Faces: A Myth Retold. 1956. New York and London: Harcourt, Brace, 1980. Print.

---. "To Arthur Greeves." 18 October 1931. Collected Letters vol. 1, 977.

---. “To Clyde Kilby." 10 February 1957. Collected Letters vol. 3, 830-1.

---. "To Father Peter Milward, SJ.” 24 September 1959. Collected Letters vol. 3, 1090.

---. “To Katharine Farrer.” 2 April 1955. Collected Letters vol. 3, 589-90.

Macksey, Richard, and Eugenio Donato, eds. The Structuralist Controversy: The Languages of Criticism and the Sciences of Man. 1970. Baltimore: Johns Hopkins UP, 1972. Print.

Milbank, John. "Fictioning Things: Gift and Narrative." Religion \& Literature 37.3 (2005): 1-35. Print.

Myers, Doris T. Bareface: A Guide to C. S. Lewis's Last Novel. Columbia: U of Missouri $P, 2004$. Print.

Panayotakis, Costas. "Vision and Light in Apuleius' Tale of Psyche and Her Mysterious Husband," Classical Quarterly 51.2 (2001): 576-83. Print.

Schakel, Peter J. Reason and Imagination in C. S. Lewis: A Study of Till We Have Faces. Grand Rapids: Eerdmans, 1984. Print.

Schrock, Chad. "A Myth of Hubris in Till We Have Faces." VII: An Anglo-American Literary Review 25 (2008):13-32. Print.

Struck, Peter T. Birth of the Symbol: Ancient Readers at the Limits of Their Texts. Princeton: Princeton UP, 2004. Print.

Tolkien, J. R. R. "On Fairy-Stories." The Monsters and the Critics and Other Essays. Ed. Christopher Tolkien. 1983. London: HarperCollins, 1997. 109-161. Print.

Williams, Charles. "The Way of Exchange." The Image of the City and Other Essays. Ed. Anne Ridler. London: Oxford UP, 1958. 147-54. Print. 